\section{Safety of Anti-Tumor Necrosis Factor Agents in Rheumatic Potential Carriers of Occult Hepatitis B Virus}

\section{To the Editor:}

We read with interest the article by Kim, et $\mathrm{ll}^{1}$ regarding the possible reactivation of potential occult hepatitis B virus (HBV) infection by use of tumor necrosis factor- $\alpha$ (TNF- $\alpha$ ) blockers in the treatment of rheumatic diseases. We describe our recent experience and review the literature, in order to illustrate the problem of the treatment of autoimmune patients who also have chronic or resolved HBV infection, and the difficulty of its resolution.

It is well known that immunosuppressive agents can induce viral reactivation $^{2}$, but data on the rate of HBV reactivation in patients with chronic HBV infection treated with anti-TNF agents are limited. Even fewer data are available on HBsAg-negative anti-HBc-carriers, who are considered potential occult carriers of $\mathrm{HBV}$, and no recommendations are available for treatment of this type of patient.

Our experience consists of 12 Italian patients included in a prospective study. Their demographic and clinical characteristics are reported in Table 1. HBV infection was not discovered until the routine investigation leading up to anti-TNF- $\alpha$ therapy. This therapy became necessary because of loss of efficacy of disease-modifying antirheumatic drugs or appearance of adverse events, including liver toxicity in some cases. Patients' serology results indicated they were potential occult carriers of $\mathrm{HBV}^{3}$. All were HBV-DNA-negative and in no case was antiviral prophylaxis given. Blood analyses (blood cell counts, aminotransferase levels, hepatitis B serological patterns, HBV-DNA testing by polymerase chain reaction) were performed before anti-TNF- $\alpha$ treatment and subsequently at least every 3 months. During the followup period (mean $41.08 \pm 33.93$ months, range 9-104 months), no patient had raised levels of aminotransferases or HBV reactivation (HBsAg or HBV-DNA detection).

Only 2 case reports of TNF antagonist-related HBV reactivation in HBsAg-negative, anti-HBc-positive patients have been described ${ }^{4,5}$. Kim,

Table 1. Baseline demographic and clinical features of patients.

\section{Characteristic}

$\begin{array}{lr}\text { Sex, men:women } & 5: 7 \\ \text { Age, mean } \pm \text { SD yrs } & 53.00 \pm \\ \text { Diagnosis } & 5 \\ \quad \text { Rheumatoid arthritis } & 5 \\ \text { Psoriatic arthritis } & 1 \\ \quad \text { Seronegative arthritis } & 1 \\ \text { Entero-spondyloarthropathy } & \\ \text { Disease duration, mean } \pm \text { SD 101.67 } \pm 63.40 \text { months (rang } \\ \text { Previous therapies*, no. patients } & 9 \\ \text { Methotrexate } & 6 \\ \text { Cyclosporine } & 4 \\ \text { Sulfasalazine } & 4 \\ \text { Hydroxychloroquine } & 3 \\ \text { Leflunomide } & 2 \\ \text { Gold salts } & \end{array}$

Anti-TNF treatment duration, mean \pm SD $41.08 \pm 33.93$ months (range 9 to 104 )

Type of TNF inhibitor, no. patients

Etanercept

Adalimumab

Concomitant DMARD, no. patients

Methotrexate

Sulfasalazine

5

1 23 to 226

4

\footnotetext{
* Since some patients were treated with more than one agent, the cumulative number exceeds $100 \%$. TNF: tumor necrosis factor; DMARD: disease modifying antirheumatic drug.
}

et $a l^{1}$ described 88 patients with potential occult HBV infection, who were found to have a significantly higher risk to develop persistent abnormal liver function tests, compared to the HBcAb-negative group. Kim and colleagues could not confirm the association of abnormal liver function tests with a reactivation of occult $\mathrm{HBV}$ infection, since they did not perform HBV-DNA testing.

On the other hand, other authors do not confirm the same findings. Raftery, et $a l^{6}$ described a woman with rheumatoid arthritis who was HBsAg-negative, anti-HBc-positive, and anti-HBs-positive. She was given etanercept combined with methotrexate without lamivudine or adefovir, with no complications or evidence of HBV reactivation even after 2 years of treatment. Vassilopoulos, $\mathrm{et}_{\mathrm{al}} \mathrm{did}^{\mathrm{did}}$ not detect elevated levels of aminotransferases or HBsAg or HBV-DNA positivity in 19 rheumatic patients with resolved HBV infection during anti-TNF treatment.

Similar findings were reported by Charpin and colleagues ${ }^{8}$ in a recent study of 21 rheumatic patients whose HBV serology suggested the carrier status, treated with TNF- $\alpha$ inhibitors during a 3 -year period. Jansen ${ }^{9}$ confirmed these results in patients with a past hepatitis B serological pattern. Moreover, Caporali, et $a l^{10}$ recently found no $\mathrm{HBV}$ reactivation during a followup period of $42.52 \pm 21.33$ months in 67 anti-HBc carriers who had chronic arthritis treated with anti-TNF- $\alpha$ therapy without lamivudine prophylaxis.

In agreement with these reports ${ }^{6,7,8,9,10}$, our case series results confirm the substantial safety of TNF- $\alpha$ blockers in rheumatic patients previously exposed to HBV receiving no HBV prophylaxis.

On the whole, all these data do not completely resolve the problem of the safety of anti-TNF agents in rheumatic patients with potential occult $\mathrm{HBV}$ infection, and suggest that close monitoring of clinical signs and transaminase levels and/or viral load is essential throughout the anti-TNF treatment period in order to detect early viral reactivation; its occurrence is probably unlikely, but represents a risk to be identified and that cannot be totally ruled out.

Further reporting of such cases is important to inform and clarify a subject for which there is still a paucity of data, and to find common guidelines for management of this particular group of patients.

CHIARA GIANNITTI, MD, Rheumatology Unit, Department of Clinical Medicine and Immunological Science, University of Siena, Siena; GIAN DOMENICO SEBASTIANI, MD, Rheumatology Unit, San Camillo-Forlanini Hospital, Rome; STEFANIA MANGANELLI, MD; MAURO GALEAZZI, MD, Rheumatology Unit, Department of Clinical Medicine and Immunological Science, University of Siena, Policlinico Le Scotte, Viale Bracci 1, Siena, Italy. Address correspondence to Dr. Giannitti; E-mail: chiara.giannitti@libero.it

\section{REFERENCES}

1. Kim YJ, Bae SC, Sung YK, Kim TH, Jun JB, Yoo DH, et al. Possible reactivation of potential hepatitis B virus occult infection by tumor necrosis factor- $\alpha$ blocker in the treatment of rheumatic diseases. J Rheumatol 2010;37:346-50.

2. Calabrese LH, Zein NN, Vassilopoulos D. Hepatitis B virus (HBV) reactivation with immunosuppressive therapy in rheumatic diseases: assessment and preventive strategies. Ann Rheum Dis 2006; 65:983-9.

3. Allain JP. Occult hepatitis B virus infection. Transfus Clin Biol 2004;11:18-25.

4. Madonia S, Orlando A, Scimeca D, Olivo M, Rossi F, Cottone M. Occult hepatitis B and infliximab-induced HBV reactivation. Inflamm Bowel Dis 2007;13:508-9.

5. Montiel PM, Solis JA, Chirinos JA, Casis B, Sánchez F, Rodríguez S. Hepatitis B virus reactivation during therapy with etanercept in an HBsAg-negative and anti-HBs-positive patient. Liver Int 2008;28:718-20.

6. Raftery G, Griffiths B, Kay L, Kane D. Chronic viral hepatitis and TNF-alpha blockade. Rheumatology 2007;46:1381. 
7. Vassilopoulos D, Apostolopoulou A, Hadziyannis E,

Papatheodoridis GV, Manolakopoulos S, Koskinas J, et al.

Long-term safety of anti-TNF treatment in patients with rheumatic diseases and chronic or resolved hepatitis B virus infection. Ann Rheum Dis 2010;69:1352-5.

8. Charpin C, Guis S, Colson P, Borentain P, Mattéi JP, Alcaraz P, et al. Safety of TNF-blocking agents in rheumatic patients with serology suggesting past hepatitis B state: results from a cohort of 21 patients. Arthritis Res Ther 2009;11:R179.

9. Jansen TL. When rheumatology meets hepatology: are anti-TNFs safe in hepatitis B virus carriers? Arthritis Res Ther 2010;12:103.

10. Caporali R, Bobbio-Pallavicini F, Atzeni F, Sakellariou G, Caprioli M, Montecucco C, et al. Safety of tumor necrosis factor- $\alpha$ blockers in hepatitis B virus occult carriers (hepatitis B surface antigen negative/anti-hepatitis B core antigen positive) with rheumatic diseases. Arthritis Care Res 2010;62:749-54.

J Rheumatol 2011;38:4; doi:10.3899/jrheum.101157 